\title{
NOTA DE OPINIÓN
}

\section{Familias y política pública}

Actualmente, el país se encuentra en el proceso de diseño y formulación de la Política Pública de Apoyo y Fortalecimiento a la Familia en Colombia; para ello, una Comisión Nacional está realizando talleres regionales. El 24 y 25 de noviembre de 2011 se realizó uno de estos talleres en la ciudad de Cali, y en él participaron funcionarios, representantes de diversas ONG y de la Administración Municipal, y delegados regionales del suroccidente colombiano. Estos actores debatieron sobre la problemática de la familia y sobre la familia "soñada". Al finalizar la jornada se le sugirió a la delegada nacional que, a propósito de la reflexión generada sobre la democracia, la diversidad, las tipologías y la inclusión, la política debería llamarse Política Pública de Apoyo y Fortalecimiento a las familias en Colombia. Ella respondió así: “sí, eso lo vamos a hacer en el plano operativo, pero en el plano epistemológico no se puede hacer, hay una gran discusión nacional sobre esto y el Comité Técnico y los demás comités están hablando sobre la familia”. Después de esta respuesta, y de una gran sorpresa, hay que decir que a este país le sobra politica pública y le falta OTREDAD.

Pareciera que es sólo un problema de denominación, pero no es así: el asunto es de concepción y disposición (en términos del lugar que ocupo y que ocupan los demás). Aquí hay política pública para "todo": para la primera infancia, para la juventud, para la prevención, protección y atención al desplazamiento interno forzado, para la salud sexual y reproductiva, para la discapacidad. No: los problemas no se resuelven sólo 
con políticas públicas; tendremos que preguntarnos qué está pasando con el Estado-Nación y con sus actores más importantes, "los ciudadanos", y por qué las múltiples diferencias y diversidades no se pueden acoger, respetar y resguardar en la categoría "los ciudadanos". ¿Es acaso que hay que repensar esto del Estado-Nación como garante de deberes y derechos? ¿O será acaso que lo que se debe repensar son los argumentos de las movilizaciones al estilo guetos para reivindicar particularidades y singularidades en aras de defenderse de una élite también muy particular y singular que habla otorgándose el poder de la vocería de un "todos"? No se trata de una añoranza de los Estado-Nación del siglo pasado, porque sería desconocer su evidente transformación; se trata más bien de que el EstadoNación sea el garante del reconocimiento y no de la diferencia per se, en tanto que se trata de interpelar la diferencia, cualquiera que ésta sea, desde el reconocimiento y no desde la fragmentación a la que se está tendiendo con las políticas públicas.

Tal vez quienes formulan y ejecutan las políticas públicas en este país son demasiado conservadores para concebir y tener disposición a la otredad. Entonces no llamemos, ni engañemos, ni desdibujemos la participación con talleres, cuando el llamado a participar ya está resuelto y definida la familia o los tipos de familia que se van a apoyar y reconocer.

Así entonces, la Política Pública de Apoyo y Fortalecimiento a la Familia en Colombia se sancionará y reglamentará muy a pesar del reconocimiento multiétnico y plural de la Constitución Colombiana de 1991, y será así en tanto ella misma encarna esta contradicción con la misma definición de familia que allí se encuentra consignada.

Hacemos un llamado como trabajadores (as) sociales al Consejo Nacional de Trabajo Social -CONETS- para que no sólo se adelanten acciones logísticas y operativas para el desarrollo de estos talleres, sino también -y esto es muy importante- que se propicien y generen espacios de debate y concertación entre las unidades académicas para contribuir política y académicamente a este tipo de propuestas, en tanto que está la necesidad de revisar y tener en cuenta reflexiones teóricas de juicio y las realidades de la diversidad humana, que permitan comprender y realizar propuestas de intervención con familias en un 
contexto social que cuestiona las lógicas de relación establecidas e invita a redimensionarlas y reconfigurarlas para constituir otro tipo de relaciones.

Paula Andrea Velásquez López Sección de Orientación y Promoción Familiar Escuela de Trabajo Social y Desarrollo Humano Universidad del Valle Santiago de Cali, 2011 